\title{
Morphometric Relationships as Indicative of Silvicultural Interventions for Brazilian Pine in Southern Brazil
}

\author{
André Felipe Hess ${ }^{1}$, Táscilla Magalhães Loiola ${ }^{2}$, Myrcia Minatti ${ }^{3}$, Gabriel Teixeira da Rosa ${ }^{1}$, \\ Isadora de Arruda Souza ${ }^{1}$, Emanuel Arnoni Costa ${ }^{1}$, Luis Paulo Baldissera Schorr ${ }^{1}$, \\ Geedre Adriano Borsoi ${ }^{1} \&$ Thiago Floriani Stepka ${ }^{1}$ \\ ${ }^{1}$ Department of Forestry Engineering, State University of Santa Catarina, Brazil \\ ${ }^{2}$ Department of Forestry Engineering, Federal University of Santa Maria, Brazil \\ ${ }^{3}$ Department of Forestry Engineering, Federal University of Paraná, Brazil \\ Correspondence: André Felipe Hess, Department of Forestry Engineering, State University of Santa Catarina, \\ Brazil. E-mail: hessandre@yahoo.com.br
}

Received: March 21, 2018

doi:10.5539/jas.v10n7p110

\author{
Accepted: May 1, $2018 \quad$ Online Published: June 15, 2018 \\ URL: https://doi.org/10.5539/jas.v10n7p110
}

\begin{abstract}
Silvicultural interventions are necessary to control the competition and to maintain the forest structure. Thus, this work aimed to know the interactions between dendro/morphometric variables to indicate density interventions in Brazilian pine Forest. Dendrometric and morphometric variables were measured from 186 individual trees of this species, which were distributed in diametric classes at three sites. With the variables were fitted models for the relationships between the degree of slenderness and the potential crown diameter as a function of the number of trees per hectare. The fit indicated that the variables showed interaction and the relationship can be described by linear function explaining between 51.9 and $99.3 \%$ of the variance between morphometry and forest density. This adjustment and information can be used to indicate the optimum density according to the amplitude of each index. The results show that the morphometric indexes and their interaction indicate the period of the interventions, having relation with the characteristics of the site, the diametric structure and the dynamics of the forest growth.
\end{abstract}

Keywords: plant morphology, density, forest measurement, regression analysis

\section{Introduction}

Araucaria forests or Brazilian pine forests in southern Brazil were made unfeasible through forest legislation for the application of forest management practices. However, the total conservation of a species is more detrimental to its survival than its use with sustainable management. As well as, it affects the future structural dynamics of the forest, growth rates, natural regeneration and genetic adaptation to changes in the environment (Beckert et al., 2014; Hess et al., 2016).

The problem to be faced is the acquisition of tools and techniques that allow the sustainable management of this important forest resource in southern Brazil, since the Araucaria angustifolia (Bertol.) Kuntze (Brazilian pine) tree has income from the use of wood (high commercial value) and edible seeds. Thus, the proposal presented in the study is to evaluate the interaction between morphometric variables and the density of trees to recognize the period of silvicultural interventions and to maintain the dynamics of forest growth and regeneration.

Static and dynamic morphometric studies in woody plants are of fundamental interest in directing and adapting silvicultural practices, such as thinning, pruning and harvesting (Roman et al., 2009; Fey et al., 2014). Interdimensional morphometric relationships have been used to describe behavior in native forests (Durlo \& Denardi, 1998; Tonini \& Arco-Verde, 2005; Roman et al., 2009; Costa et al., 2016) and in exotic species (Nutto, 2001; Weber et al., 2013) to enhance the production of wood.

The morphometry of the tree species allows to predict the space required for each tree during its development. It evaluates the degree of competition among individuals and makes inferences about stability and vitality as well as the productivity of each individual (Roman et al., 2009). The stability of the tree, evaluated by the degree of slenderness, indicates that the higher its value, the more unstable the tree. According to the same author, individuals with the highest values for this index are those that are in a high degree of competition. Their crowns 
are located in the middle stratum of the forest, indicating a need for silvicultural intervention. Values vary with species, density, competition, age and growth conditions.

The vulnerability of individual tree and forest to the wind is based on a combination of tree attributes (species, age, sanity, total height, crown size, root characteristics), forest conditions (species, density and surrounding forest structure), local topography, soil (texture, depth) and predominant pattern of winds (Ruel, 2000).

The degree of slenderness serves as an index of tree stability or resistance to displacement with the wind. A low value usually indicates a longer crown, lower center of gravity, and better development of the root system. However, trees with higher values for the degree of slenderness are more susceptible to wind damage. Actions to improve tree and forest stability can limit such damage. Thus, given the importance of the degree of slenderness as an index of resistance for trees, their knowledge is important, considered to be a measure of their stability, especially of conifers, as well as the development of models that can predict these values (Eguakun \& Oyebade, 2015).

The size and shape of the crown influence its photosynthetic and production capacity. For Wadsworth (2000) trees of the upper stratum have slightly dense horizontal crowns and those of the lower stratum have vertical and deep crowns. The ratio of crown diameter to diameter of breast height expressed how many times the crown diameter is greater than the diameter. This ratio can be used to manage the forest when a certain diameter of interest is forecast for an adequate number of trees per hectare, accompanying changes in growth dynamics. Thus, the relationship is also an indicator of the period for silvicultural interventions.

The use of morphometric indexes and their interactions can be used to describe the need for silvicultural interventions in order to maintain the forest growth structure. It can predict competition with an adequate density of trees per surface and with changes in tree shape. Thus, the hypothesis of the study was to verify if these relationships, when confronted, indicate the capacity to predict forestry interventions. These are adequate according to the dynamics of structure and density in uneven Araucaria Forest. Because this forest typology after 40 years without management requires silvicultural interventions for the perpetuity of the remaining with Brazilian pine in southern Brazil (Silveira et al., 2018; Hess et al., 2018).

In this study, the relationship between the degree of slenderness (hd) and the potential crown diameter (pcd) was investigated as a function of the number of trees, aiming to identify the period of intervention in density for stability and lateral expansion of the crown. The hypotheses highlighted are (1) the morphometric variables associated with density serve as indicators for silvicultural intervention; and (2) the interaction between variables expresses changes in structural dynamics better than isolated variables.

The problem is that the studies generally analyze the morphometric indices in an isolated way, not indicating at the same time, what is the ideal value for the species, site or density of trees. The aim of this work was to relate and adjust the morphometric indexes of the degree of slenderness and potential crown diameter in function of density (N/ha), as a possibility to define the period of silvicultural interventions according to the dynamics of growth, structure and shape for individual trees of Brazilian pine in Mixed Ombrophilous Forest.

\section{Method}

\subsection{Areas of Study and Data Collection}

The region of the three sites of the study (Figure 1) is characterized by climate Cfb, according to Köppen classification, temperate climate, constantly wet and without a dry season. In São Joaquim (SJQ) the altitude is $1,166 \mathrm{~m}$ and the average annual temperature of $14{ }^{\circ} \mathrm{C}$ and precipitation of $1,740 \mathrm{~mm}$. Urupema (URU) the altitude is $1,259 \mathrm{~m}, 13.7^{\circ} \mathrm{C}$ of average temperature and $1,722 \mathrm{~mm}$ of precipitation and Painel (PNL) has an altitude of $1,123 \mathrm{~m}, 15.3{ }^{\circ} \mathrm{C}$ and $1,543 \mathrm{~mm}$ of annual precipitation (Alvares et al., 2013). The typology of the region is the Mixed Ombrophilous Forest or Araucaria Forest. 


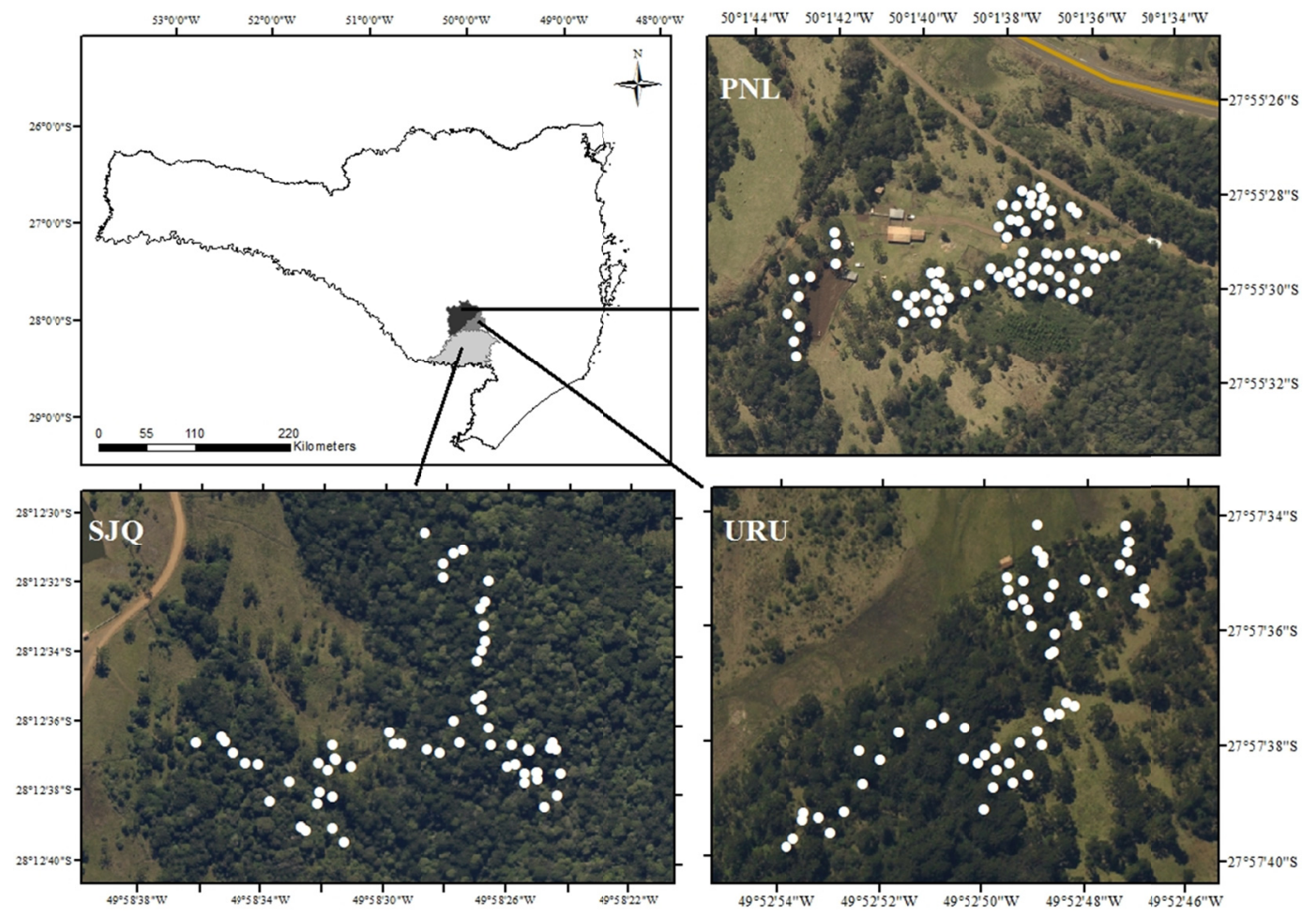

Figure 1. Map indicating the location and coordinates of the individual trees in study sites and the sampled forests (Mixed Ombrophilous Forest) with predominance of Brazilian pine. São Joaquim (SJQ); Painel (PNL) and Urupema (URU)

The data used to adjust the functions were measured from individual Brazilian pine trees at the three study sites with remnants of Araucaria Forest in southern Brazil, Santa Catarina. In all 186 trees were selected using a methodology focused on the individual tree, covering the amplitude of the diametric classes (Table 1). From each tree were measured the dendrometric variables diameter at breast height (d), total height (h) and four crown rays, in the cardinal directions (North, East, South and West), using Trupulse 200 equipment and compass.

The predominant vegetation is the Mixed Ombrophilous Forest typology, with predominance of $A$. angustifolia (Brazilian pine) species. The mean annual diametric increment of the lowest classes is $0.31 \mathrm{~cm} /$ year, while the other classes obtained increment from 0.6 to $0.9 \mathrm{~cm} /$ year (Loiola, 2016). The density of the species in the remnants of the Araucaria Forest ranges from 300 to more than 500 trees per hectare. It presents J-inverted distribution, competition, low natural regeneration, low ingress rate and stagnant growth rate. This information indicates the commitment to develop a future forest structure, indicating silvicultural intervention as an alternative to forest conservation (Ricken, 2014; Silveira et al., 2018). The Araucaria Forest presents these conditions because it has been for more than 40 years without any forest management activity.

\subsection{Morphometry and Interdimensional Relationships}

With the data, the average crown radius was calculated, the crown diameter, the degree of slenderness and the adjustment of the model to crown diameter as a function of the diameter at breast height:

$$
\begin{gathered}
\overline{\mathrm{cr}}=\sum_{\mathrm{i}=1}^{\mathrm{n}=4} \mathrm{cr} / 4 \\
\mathrm{~cd}=2 \cdot \overline{\mathrm{cr}} \\
\mathrm{hd}=\mathrm{h} / \mathrm{d} \\
\mathrm{cd}=\beta_{0}+\beta_{1} \cdot \mathrm{d}
\end{gathered}
$$

Where,

$\overline{c r}$ : median crown radius in $\mathrm{m}$; cd: crown diameter in $\mathrm{m}$; hd: degree of slenderness; $\mathrm{h}$ : total height in $\mathrm{m}$; $\mathrm{d}$ : diameter at breast height in $\mathrm{cm}$. 
The data for (cd) were submitted to covariance analysis, in order to identify if there are differences in level and slope for this variable in the study sites (Kaps \& Lamberson, 2004). It was considered (cd) and its variability as a dependent variable that explains particular aspects of the site and number of trees per hectare, while (d) was considered as continuous independent variable. The application of the model proposed by Kaps and Lamberson (2004) including the effect of local and simple linear regression is shown by the Equation 5 :

$$
y_{i j}=\beta_{0}+\tau_{i}+\beta_{1} x_{i j}+\sum i \beta_{2 i}(\tau \cdot x)_{i j}+\varepsilon_{i j} \quad i=1, \ldots a ; j=1, \ldots n
$$

Where,

$\mathrm{y}_{\mathrm{ij}}$ : observation $\mathrm{j}$ of group $\mathrm{i} ; \tau_{\mathrm{i}}$ : group effect; $\beta$ 's: regression parameters; $\mathrm{x}_{\mathrm{ij}}$ : value of continuous independent variable for observation $\mathrm{j}$ of group $\mathrm{i} ;(\tau \cdot \mathrm{x})_{\mathrm{ij}}$ : interaction of group $\times$ covariable; $\varepsilon_{\mathrm{ij}}$ : random error.

Based on the observed values for (cd) a new intercept can be defined analytically by adding a proportional value obtained from the relation between the minimum and the maximum (cd) that the tree reaches. After the Equation (4) was readjusted to obtain the potential crown diameter (pcd) with Equation (6), being defined as in Costa et al. (2016). The value (x) can be defined for the set of data if (cd) is similar to the sites, or a value is defined for each site if there is no similarity between the growth dynamics of the crown shape.

$$
\operatorname{pcd}=\left(\beta_{0}+\left[\mathrm{x} \cdot \beta_{0}\right]+\beta_{1} \cdot \mathrm{d}\right)
$$

Where,

pcd: potential crown diameter in $\mathrm{m}$; $\mathrm{d}$ : diameter at breast height in $\mathrm{cm} ; \beta$ 's: regression parameters; $\mathrm{x}$ : value of the ratio defined between the minimum and maximum (cd) obtained from the regression line and added to the intercept.

Thus, the occupation of crowns was established according to Equation (6) and the number of trees calculated with the Equation (7), a methodology proposed by Krajicek et al. (1961) and Costa et al. (2016):

$$
\mathrm{N} / \mathrm{ha}=\frac{40000}{\pi(\mathrm{pcd})^{2}}
$$

Where,

$\mathrm{N} / \mathrm{ha}$ : number of trees per hectare; $\pi$ : constant; pcd: potential crown diameter in $\mathrm{m}$.

With the value of the logarithm of the number of trees per hectare corresponding to each potential crown diameter, the slope degree equation was adjusted according to the number of trees:

$$
\text { hd }=\mathrm{e}^{\beta_{0}+\beta_{1} \operatorname{lnN}}
$$

Where,

hd: degree of slenderness; $\operatorname{lnN}$ : neperian logarithm of the number of trees per hectare; $\beta$ 's: regression parameters.

It was also established the interaction of the potential crown diameter as a function of the number of trees per hectare, with the equation:

$$
\operatorname{pcd}=\mathrm{e}^{\beta_{0}+\beta_{1} \operatorname{lnN}}
$$

Where,

pcd: potential crown diameter in $\mathrm{m}$; $\operatorname{lnN}$ : neperian logarithm of the number of trees per hectare; $\beta$ 's: regression parameters.

\subsection{Data Analysis}

In order to evaluate the accuracy of Equations (4), (8) and (9), the coefficient of determination $\left(\mathrm{R}^{2}\right)$, the standard error of the estimation (Syx) and the graphic analysis of the residues as a function of the estimated variable were used. All analyzes were processed in the Statistical Analysis System (SAS, 2004).

The relationships and constructed interaction were plotted and analyzed graphically to indicate the appropriate number of trees according to the changes in the value of the indices (hd) and (pcd) following the changes in the forest structure dynamics over time. Thus, we can establish the number of trees to a desired diameter and degree of slenderness (suitable) and indicate silvicultural intervention.

\section{Results}

With the 186 trees sampled, the dendrometric information, the potential crown diameter (Equation 6) and the number of trees per hectare (Equation 7) were obtained for each study site (Table 1). The SJQ site presented higher average values for the dendrometric variables. While URU showed higher (d) maximum, lower (d) minimum and higher values for potential crown diameter, consequently, greater lateral crown growth space and 
fewer trees per hectare. The PNL site presented the lowest values for (pcd), allowing a higher density of trees per hectare. This site, because it presents a greater number of trees should present a higher value for the degree of slenderness (hd), as it did not occur, can be indicative of impediment of the site to grown height.

Table 1. Dendrometric, morphometric and density information for native araucaria forest for the three study sites in southern Brazil, SC

\begin{tabular}{|c|c|c|c|c|c|c|c|c|c|c|c|c|c|c|c|}
\hline & \multicolumn{5}{|c|}{ SJQ } & \multicolumn{5}{|c|}{ URU } & \multicolumn{5}{|c|}{ PNL } \\
\hline & $\mathrm{d}$ & $\mathrm{h}$ & pcd & hd & $\mathrm{N}$ & $\mathrm{d}$ & $\mathrm{h}$ & pcd & hd & $\mathrm{N}$ & $\mathrm{d}$ & $\mathrm{h}$ & pcd & hd & $\mathrm{N}$ \\
\hline$\overline{\bar{x}}$ & 41.4 & 17.0 & 11 & 43.4 & 124 & 36.6 & 14.2 & 13.7 & 41.7 & 71 & 37.5 & 14.4 & 4.9 & 39.1 & 243 \\
\hline M & 60.2 & 26.1 & 15 & 77.1 & 344 & 70.0 & 23.0 & 19.3 & 82.7 & 109 & 62.7 & 19.0 & 8.1 & 55.9 & 405 \\
\hline $\mathrm{m}$ & 20.1 & 11.9 & 6.1 & 24.1 & 56 & 18.8 & 8.8 & 10.8 & 19.9 & 34 & 23.6 & 11.0 & 3.2 & 26.2 & 113 \\
\hline$\sigma$ & 9.8 & 2.7 & 2.2 & 12.1 & 62.6 & 11.0 & 2.9 & 1.8 & 12.9 & 17.5 & 6.7 & 1.9 & 0.7 & 7.0 & 54.5 \\
\hline
\end{tabular}

Note. SJQ, URU and PNL: study sites São Joaquim, Urupema and Painel, Santa Catarina; d: diameter at breast height in cm; h: total height in $\mathrm{m}$; pcd: potential crown diameter in $\mathrm{m}$; hd: degree of slenderness; N: number of trees per hectare; $\bar{x}$ : mean values of the variables; M: maximum value; m: minimum value; $\sigma$ : standard deviation.

The mean degree of slenderness was similar for the sites. These values demonstrate trees with moderate degree of stability and not subject to damages by the wind. The results for the degree of slenderness indicate stable trees, characteristic of the ecological habit of the species (Sanquetta et al., 2013) related to density, competition, site and age. According to Selle and Vuaden (2010), the decrease in the degree of slenderness with the increase of the height of the trees indicates that these each meter that grow in height, grow more than an inch in (d), becoming more robust and stable. Thus, the mean amplitude of the values for the degree of slenderness indicates that in this interval the morphometric equilibrium point due to demands for light, water, nutrient and dimensional stability (Sanquetta et al., 2013). The results show that araucaria trees have different growth rates for hd and pcd. In sites with higher density lower is the pcd. This indicates that each site should receive silvicultural intervention at different times.

The covariance analysis for the relation between crown diameter (cd) and diameter (d) showed a difference in the level and slope of the regression line (Figure 2A) for site and $\mathrm{d} \times$ site interaction. Covariance was significant with probability $(\mathrm{p}<0.0001)$ and can be described by linear function (Equation 4$)$, which explains $75 \%$ of the variation for the morphometric variable (cd). The residuals of the adjustment of the equations generated for each site (Figures 2B, 2C and 2D) did not present bias, justifying the adjusted equations (Table 2). 

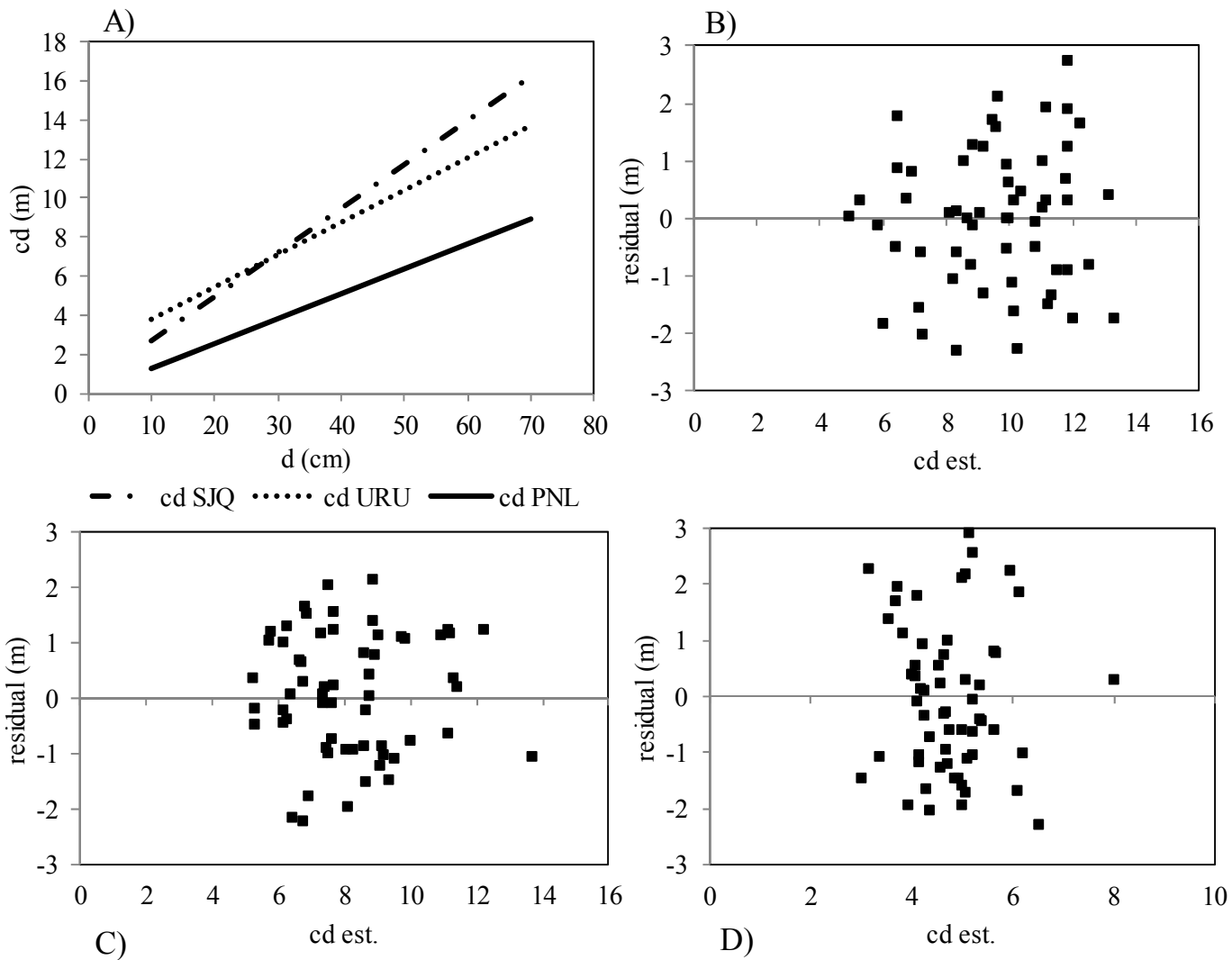

Figure 2. Crown diameter (cd) as a function of diameter at breast height (d) showing differences in growth dynamics of the crown and relative growth capacity at each site (A). Residual dispersion to fit the equations between (cd) and (d) for the SJQ (B), URU (C) and PNL (D) sites

Note. cd: crown diameter; d: diameter of breast height; SJQ, URU, PNL: São Joaquim, Urupema and Painel site.

Thus, the need for regression and proportional values for each study site was verified, with the equations for (pcd) described by the following expressions (Table 2). The value of the proportion added to the value of the intercept was established between 2.5 and 2.6, delimiting the maximum size that the crown diameter can reach for the species at each study site. Due to the lower values for $(\mathrm{dc})$, PNL presented non-significant coefficient $\left(\beta_{0}\right)$, being the fit of the model fulfilled without the value of the intercept.

Table 2. Equations for potential crown diameter and proportional value added to the intercept and their statistical adjustment criteria for araucaria study sites in southern Brazil

\begin{tabular}{llll}
\hline Site & Equation & $\mathrm{R}^{2}(\%)$ & Syx $(\mathrm{m})$ \\
\hline SJQ & $\mathrm{pcd}=0.44546+(2.5 \times 0.44546)+0.22545 \times \mathrm{d}$ & 68.1 & 1.5 \\
URU & $\mathrm{pcd}=2.14368+(2.6 \times 2.14368)+0.16526 \times \mathrm{d}$ & 67.8 & 1.2 \\
PNL & $\mathrm{dcp}=2.6+0.12757 \times \mathrm{d}$ & 91.1 & 1.5 \\
\hline
\end{tabular}

Note. SJQ; URU; PNL: São Joaquim, Urupema and Painel sites; pcd: potential crown diameter in m; d: diameter at breast height; $\mathrm{R}^{2}$ : coefficient of determination in \%; Syx: standard error of the estimate $(\mathrm{m})$.

After obtaining the (pcd), number of trees per hectare (Equation 7) and the degree of slenderness (hd), it was possible to adjust Equation (8). This equation explained between 51.9 and $72.5 \%$ of the variance and Equation (9) that explained between 98.5 and $99.3 \%$ of the variance (Table 3). The adjustment is indicative of the interaction between the potential crown diameter (pcd) and the degree of slenderness (hd) with the number of trees occupying the available space (Figure 3). The crossing of the curves, indicate the point of intervention to regulate the density, maintaining the rate of increase, crown growth, vitality and stability of the trees. Thus, as 
the trees need space for the increase in diameter of the crown, and they acquire stability (less value of the degree of slenderness) there is need of intervention for reduction in the number of individuals.

Table 3. Equations adjusted for the interaction between morphometric variables and density for the three study sites in araucaria native forest in southern Brazil, SC

\begin{tabular}{llll}
\hline Site & Equation & $\mathrm{R}^{2}(\%)$ & Syx \\
\hline SJQ & $\mathrm{hd}=\mathrm{e}^{-69.89951+24.02087 \cdot \ln N}$ & 72.5 & 6.5 \\
URU & $\mathrm{hd}=\mathrm{e}^{-112.05+36.37695 \cdot \ln N}$ & 52.5 & 8.8 \\
PNL & $\mathrm{hd}=\mathrm{e}^{-84.0439+22.54071 \cdot \ln N}$ & 51.9 & 4.8 \\
SJQ & $\mathrm{pcd}=\mathrm{e}^{34.72481-5.04955 \cdot \ln N}$ & 98.5 & 0.27 \\
URU & $\mathrm{pcd}=\mathrm{e}^{43.49531-7.03768 \cdot \ln N}$ & 99.3 & 0.15 \\
PNL & $\mathrm{pcd}=\mathrm{e}^{27.92336-3.75759 \cdot \ln N}$ & 99.1 & 0.10 \\
\hline
\end{tabular}

Note. SJQ; URU; PNL: São Joaquim, Urupema and Painel sites; hd: degree of slenderness; pcd: potential crown diameter; $\operatorname{lnN}$ : neperian logarithm of the number of trees; $\mathrm{R}^{2}$ : coefficient of determination in \%; Syx: standard error of estimate.

With the (pcd), it was possible to estimate the crown occupation and the density corresponding to each diameter class in the study sites. The relationships between the morphometric variables and the number of trees per hectare showed (Table 4) and (Figure 3) that the highest number of trees corresponds to a higher value for the degree of slenderness (hd) and lower (pcd), being the interaction between the variables inversely proportional.
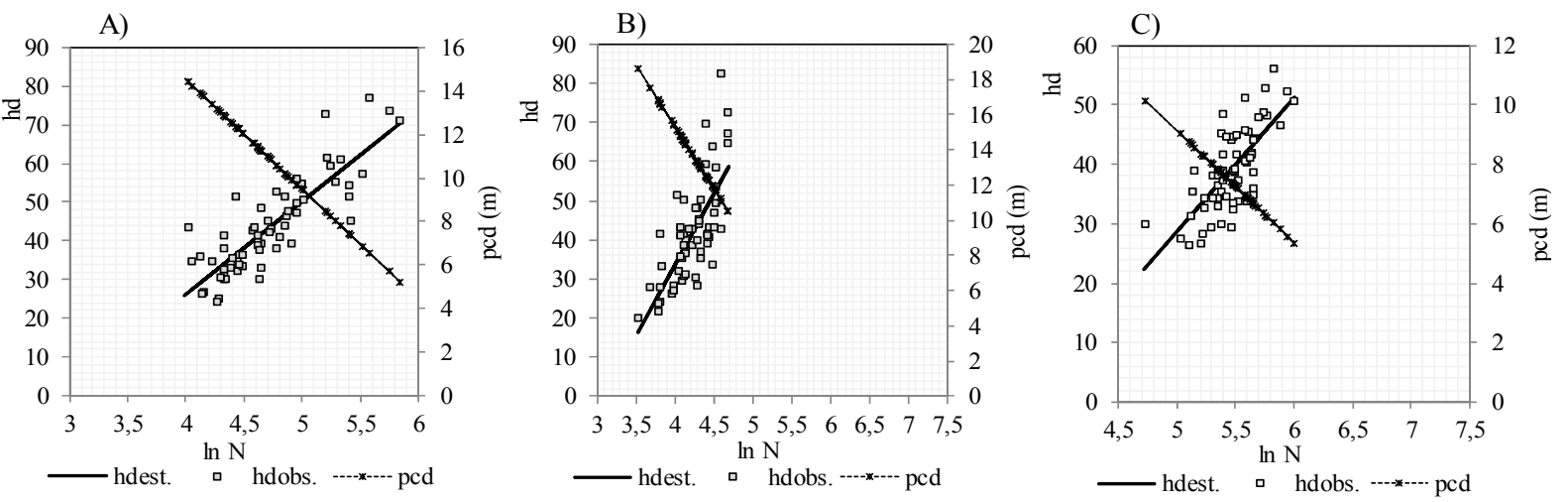

Figure 3. Morphometric relationships and their interaction with the number of trees per hectare for Araucaria Forest at three study sites in southern Brazil, SC

Note. A) São Joaquim; B) Urupema and C) Painel; hdest.: estimated degree of slenderness; hdobs.: observed degree of slenderness; pcd: potential crown diameter (m).

Eguakun and Oyebade (2015), and Adeyemi and Adesoye (2016) found Pearson negative correlation for the degree of slenderness in relation to the diameter at the breast height, basal area, volume, age and crown diameter for stands of Pinus caribea (Morelet) and native species of Oban Group Forest in southwest Nigeria, indicating that the values for the degree of slenderness decrease with the increase of these variables. 
Table 4. Number of trees corresponding to diameter class (d), potential crown diameter (pcd) and degree of slenderness (hd), for three study sites in Araucaria Forest in southern Brazil, SC

\begin{tabular}{|c|c|c|c|c|c|c|c|c|c|}
\hline \multirow{2}{*}{$\begin{array}{l}\text { Site } \\
\text { Class d }(\mathrm{cm})\end{array}$} & \multicolumn{3}{|c|}{ SJQ } & \multicolumn{3}{|c|}{ URU } & \multicolumn{3}{|c|}{ PNL } \\
\hline & pcd (m) & $\mathrm{N} / \mathrm{ha}$ & hd & pcd (m) & $\mathrm{N} / \mathrm{ha}$ & hd & pcd (m) & $\mathrm{N} / \mathrm{ha}$ & hd \\
\hline 10 & 3.8 & 875 & 93 & 9.4 & 145 & 69 & 3.9 & 848 & 68 \\
\hline 15 & 4.9 & 522 & 80 & 10.2 & 122 & 63 & 4.5 & 625 & 61 \\
\hline 20 & 6.1 & 346 & 71 & 11.0 & 105 & 57 & 5.2 & 480 & 55 \\
\hline 25 & 7.2 & 246 & 62 & 11.9 & 91 & 52 & 5.8 & 380 & 50 \\
\hline 30 & 8.3 & 184 & 55 & 12.7 & 79 & 47 & 6.4 & 308 & 45 \\
\hline 35 & 9.5 & 143 & 49 & 13.5 & 70 & 42 & 7.1 & 255 & 41 \\
\hline 40 & 10.6 & 114 & 44 & 14.3 & 62 & 38 & 7.7 & 215 & 37 \\
\hline 45 & 11.7 & 93 & 39 & 15.2 & 55 & 34 & 8.3 & 183 & 33 \\
\hline 50 & 12.8 & 77 & 35 & 16.0 & 50 & 30 & 9.0 & 158 & 30 \\
\hline 55 & 14.0 & 65 & 30 & 16.8 & 45 & 26 & 9.6 & 138 & 27 \\
\hline 60 & 15.1 & 56 & 27 & 17.6 & 41 & 23 & 10.3 & 121 & 24 \\
\hline 65 & 16.2 & 48 & 23 & 18.5 & 37 & 20 & 10.9 & 107 & 21 \\
\hline 70 & 17.3 & 42 & 20 & 19.3 & 34 & 16 & 11.5 & 96 & 19 \\
\hline
\end{tabular}

Note. SJQ; URU; PNL: São Joaquim, Urupema and Painel sites; pcd: potential crown diameter in m; d: diameter at breast height; $\mathrm{N} / \mathrm{ha}$ : number of trees per hectare; hd: degree of slenderness.

The URU site has lower density than the site supports, and may be the result of past interventions, low initial density of site occupation and forest with predominance of araucaria species. However, this contributed to the trees expanding in lateral growth reaching greater crown diameter, greater stability and less degree of slenderness. The PNL site showed lower values for (pcd) indicating lack of space for lateral crown expansion, young trees, or factors of the site that restrict growth.

Thus, in order to develop a planting with the species in these sites, the ideal initial density would be $10.5 \mathrm{~m}^{2}(3 \times$ $3.5 \mathrm{~m}$ ), that is, less than 1,000 trees per hectare. There is a need to follow the development of the dynamics of morphometric variables to propose the timing of silvicultural interventions. Considering a value for the degree of slenderness (hd) of 50 and a (pcd) of $10 \mathrm{~m}$ as an adequate crown expansion space, the results demonstrate that the sites require silvicultural intervention when the diameter reaches $35 \mathrm{~cm}$. The PNL site had a higher number of trees and a lower relation (hd), which may be a site factor and/or resource availability for growth. According to Pretzsch (2009) values for the ratio, or degree of slenderness (hd) are generally within the range of 50-150, with values below 80 being an adequate indicator of individual tree stability.

\section{Discussion}

The relation of the degree of slenderness (hd) as a function of $(\operatorname{lnN})$ presented an increasing tendency (greater number of trees, greater degree of slenderness), being a reflection of the density and competition for light. In this context, trees tend to grow more in height than in diameter. Accompanying the relationship with the dynamics of forest growth, a limit value can be stipulated for this relationship, indicating the intervention period, to guarantee stability and vitality of the individual trees.

While the relation of the potential crown diameter $(\mathrm{pcd})$ as a function of $(\ln \mathrm{N})$ presented a decreasing trend (greater number of trees, lower pcd), indicating that for growth in crown of the trees, your vitality, productivity and increment of individual trees, there is a need with the dynamics of changes of shape and dimension regulate the density.

Bošela et al. (2014) demonstrated that the hd ratio decreased with increasing crown length (crown ratio). This indicates that both parameters either react to the same external factors or influence one another. It further states that both characteristics reflected stand density and therefore, both were suitable indicators of competition intensity, and that longer tree crowns promoted the increment of stem diameter more than height.

The information corroborates with this work. The proposed adjustment (dendro/morphometric relationship) allows forest managers to decide the timing of silvicultural intervention to maintain stability, vitality and productivity of the species. Thus, in order to produce stable forests at maturity, systematic frequent thinning regimes need to be applied to the early stages of development (Bošela et al., 2014). Therefore, the relationships established in the study can be used to support these interventions. 
The study revealed that the interaction between morphometric variables is important and confirm the hypothesis of indicators of silvicultural interventions according to the development of individual trees. This was demonstrated by the intersection of the curves in the interaction, indicating an optimal point for dimension between the two relations. The crossing point of the curves also indicates the amount of trees suitable to maintain the growth of the trees. However, there are few studies that use the interaction of this information, usually using separate morphometric indexes and related to easily obtained variables, such as diameter and height. Being that there is need of continuity of the research.

Hess et al. (2018) showed that there is interactions of crown and density variables identified requirements of silvicultural interventions and the period to perform these activities according to the mean diameter of the forest or to a desired diameter. This is important information for the conservation of the Araucaria Forest structure. For the same authors the formulation of models using relationships between crown variables and density (number of trees per hectare) may show legal authorities that there is a need for silvicultural intervention to reduce competition to favor the growth, yield and production of the species. This proposition is related to modelling for individual trees.

Silvicultural interventions are necessary to control the competition and maintain the forest structure. According to Selle and Vuaden (2010), the research of the interdimensional relations of the trees is important, because it allows predicting the space required by the tree during its development, to judge the competition to which it is submitted, and to allow inferences about the stability, vitality and productivity of each individual. Therefore, it serves as a practical tool for silvicultural interventions, especially when the age of trees is not known.

To verify the relationship of these variables, Pearson positive correlations between morphometric and dendrometric variables with the crown surface area were evaluated by Hess et al. (2018). According to these authors this indicated the need for lateral space to expand the crown, its vitality and the photosynthetic production for growth. High correlation with diameter (dbh) indicates dominant trees and past capacity to win the competition by occupy the upper canopy.

The same authors concluded that larger the crown radius, larger the crown length, indicating the need for lateral space for expansion, avoiding self-thinning of the lower branches, competition and light insufficiency at the crown base, maintaining the photosynthetic capacity and growth of individual trees in the forest.

And more, the results demonstrate the effect of the change in the morphometric variables on the structure and dynamics of the forest. And construct relationships between dendro/morphometric variables, to monitor your changes with increasing diameter and density regulation are tools for forest management. And conclude, these relationships study reflects the forest dynamics, when with the passage of time it is necessary to interfere with density of the forest to follow the development structure of crown morphology and diameters (Hess et al., 2018).

In summary, the authors show that interventions are necessary prior to the absolute limit of growth in the forest. This can be determined by the maximum density, degree of occupation of the crowns, maximum biomass, maximum morphometric index or maximum mean annual increment and current annual. Thus, following the changes in the interaction between dendro/morphometric variables is a measure to manage the changes in growth during the development of the trees in the forest. Showing that the main objective is to maintain the structure of the forest and conservation of the species in a productive and socioeconomically profitable way.

Younger trees are much more flexible to changing growth conditions (light, water and nutrient availability and growing space properties - as influenced by the removal of trees through thinning) than older ones. Since the HD ratio was related to crown ratio, trees with unfavorable properties of both characteristics could be considered for removal from a stand as soon as possible. In other words, increased stand stability can best be reached by favoring trees with long (deep) crowns as early as possible in a rotation (Bošela et al., 2014).

Durlo and Denardi (1998) emphasizes that the relationship of the degree of slenderness (hd) helps in understanding the architecture of the trees and the degree of competition between them in the forest, as well as in the definition of silvicultural practices. The relation (hd) was observed empirically for several sites and species and is consistent with the expected dynamics in natural forests. The height reflects past performance and is used as a place measurement. It is related to the crown width and is a reflection of the resources potentially available to a tree. Thus $(\mathrm{N})$ reflects the competition for this resource and the interaction $\mathrm{h}-\ln (\mathrm{N})$ can provide a useful expression of the potential growth of individual trees (Vanclay, 2009).

The degree of slenderness is an excellent indicator of its long-term exposure to pre-harvest wind (Rudnicki et al., 2001), as well as in plantations the tree responds with a dynamic pattern, such as a pole or chimney, cylindrical 
shape, before first roughing. Seben et al. (2013) noted that a degree of slenderness above 100 generally indicates low stability and the tree may buckle on its own weight, while values below 80 indicate excellent stability.

The interaction between the relationships is important for the forest management, because it is possible to establish future dimensions or values for the relationships as goals, it is indicative of silvicultural intervention, allowing to predict the number of trees per hectare and to indicate the intensity of thinning. Using a reference diameter of $50 \mathrm{~cm}$ as a target $(\sim 10 \mathrm{~cm}$ more than the average for the sites), there would be a reduction of around $30 \%$ of the current average number of trees (Tables 1 and 4 ), favoring an increase in the rates increment for the remainder.

Thus, based on the current characteristics of the study sites and aiming for the forest to reach larger dimensions, the density should be regulated with interventions, remaining due to the growth dynamics, always a smaller number of trees until the end of the rotation.

As reported by Vanclay (2009), these relationships have several potential applications in the evaluation of forest resources and forest management, with the variables $\mathrm{N}, \mathrm{h}$ and $\mathrm{d}$ being easily determined. Also, because the relationship is stable over time, it can be used to forecast future growth, to evaluate existing growth models, and, as an additional constraint in estimating simultaneous constraints, to describe tree growth.

The interventions are necessary for the growing maintenance and diametric structure of the forest, as well as to favor conditions of light, natural regeneration and resources to individual trees. The adjustment of the density using morphometric variables allows managing the forest structure, size, shape and growth of individual trees and their distribution in time and space. The recommendation for silvicultural intervention in the forest suggests a decrease in hd index and promote space for crown expansion, always accompanied by measures along forest development.

\section{Conclusion}

The results showed a relationship between morphometric variables and density with precision in the fit of the equations. The morphometric indices studied can be used as indicators for the period of silvicultural intervention according to a standard reference value of each index.

The intervention information is the necessary knowledge to accommodate the changes in the diametrical structural dynamics, growth, expansion of the crown of individual trees and the density of the forest when it aims the conservation of the species.

\section{Acknowledgements}

The authors are grateful for the support of the Santa Catarina State University, Department of Forest Engineering and its Graduate Program. The FAPESC (Foundation for Research Support of the Santa Catarina State)-case number 2017TR639-financial assistance for research groups and the owners of the Araucaria Forest for the availability of this study.

\section{References}

Adeyemi, A. A., \& Adesoye, P. O. (2016). Tree slenderness coefficient and percent canopy cover in Oban Group Forest, Nigeria. Journal of Natural Sciences Research, 6(4), 9-17.

Alvares, C. A., Stape, J. L., Sentelhas, P. C., Gonçalves, J. L. M., \& Sparovek, G. (2013). Köppen’s climate classification map for Brazil. Meteorologische Zeitschrift, 22(6), 711-728. https://doi.org/10.1127/ 0941-2948/2013/0507

Beckert, S. M., Rosot, M. A. D., \& Rosot, N. C. (2014). Crescimento e dinâmica de Araucaria angustifolia (Bert.) O. Ktze. em fragmento de Floresta Ombrófila Mista. Scientia Forestalis, 42(102), 209-218.

Bošela, M., Konôpka, B., Šebeň, V., Vladovič, J., \& Tobin, B. (2014). Modelling height to diameter ratio-Na opportunity to increase Norway spruce stand in the Western Carpathians. Lesnicky casopis Forestry Journal, 60, 71-80.

Costa, E. A., Finger, C. A. G., \& Fleig, F. D. (2016). Influência da posição social nas relações morfométricas de Araucaria angustifolia. Ciência Florestal, 26(1), 225-234. https://doi.org/10.5902/1980509821116

Costa, E. A., Finger, C. A. G., Fleig, F. D., Hess, A. F., \& Marangon, G. P. (2016). Dendrograma de Manejo da densidade para uma floresta inequiânea de araucária. Floresta, 46(2), 173-184. https://doi.org/10.5380/ rf.v46i2.43449

Durlo, M. A., \& Denardi, L. (1998). Morfometria de Cabralea canjerana, em mata secundária nativa do Rio Grande do Sul. Ciência Florestal, 8(1), 55-56. https://doi.org/10.5902/19805098351 
Eguakun, F. S., \& Oyebade, B. A. (2015). Linear and nonlinear slenderness coefficient models for Pinus caribaea (Morelet) stands in southwestern Nigeria. Journal of Agriculture and Veterinary Science, 8(3), 26-30. https://doi.org/10.9790/2380-08322630

Fey, R., Malavasi, U. C., Malavasi, M. M., Schulz, D. G., \& Dranski, J. A. L. (2014). Relações interdimensionais e produtividade do pinhão-manso (Jatropha curcas L.) em sistema silvipastoril. Semina: Ciências Agrárias, 35(2), 613-624. https://doi.org/10.5433/1679-0359.2014v35n2p613

Hess, A. F., Loiola, T., Souza, I. A., \& Nascimento, B. (2016). Morphometry of the crown of Araucaria angustifolia in natural sites in southern Brazil. Bosque, 37(3), 603-611. https://doi.org/10.4067/S0717-9200 2016000300017

Hess, A. H., Silveira, A. C. da, Krefta, S. M., Santos, D. V. dos, Filho, M. D. H. V., Atanazio, K. A., ... Liesenberg, V. (2018). Crown dynamics of Brazilian pine (Araucaria angustifolia) in Santa Catarina region of Brazil. Australian Journal of Crop Science, 12(03), 449-457. https://doi.org/10.21475/ajcs.18.12. 03 pne928

Kaps, M., \& Lamberson, W. R. (2004). Biostatistics for Animal Science (p. 459). CABI Publishing, London, UK. https://doi.org/10.1079/9780851998206.0000

Krajicek, J. E., Brinkman, K. A., \& Gringrick, S. F. (1961). Crown competition: A measure of density. Forest Science, 7(1), 35-42.

Loiola, T. M. (2016). Landscape management in Araucaria forest fragments in southern Brazil, based on diameter increment (136 f., Dissertation, Master in Forest Engineering-Area: Forest Engineering, Santa Catarina State University).

Nutto, L. (2001). Manejo do crescimento diamétrico de Araucaria angustifolia (Bert.) O. Ktze. bas eado na árvore individual. Ciência Florestal, 11(2), 9-25. https://doi.org/10.5902/198050981651

Pretzsch, H. (2009). Forest dynamics, growth and yield. From measurement to model. Springer, Berlin. 664p.

Retslaff, F. A. S., Filho, A. F., Machado, S. A., Arce, J. E., \& Jaskiu, E. (2016). Diagrama de manejo da densidade para Pinus taeda no estado do Paraná. Floresta, 46(2), 185-195. https://doi.org/10.5380/ rf.v46i2.38301

Ricken, P. (2014). Increment, horizontal space and competition in natural population of Araucaria angustifolia in Santa Catarina plateau (105 f., Dissertation, Master in Forest Engineering —Area: Forest Engineering, Santa Catarina State University).

Roman, M., Bressan, D. A., \& Durlo, M. A. (2009). Variáveis morfométricas e relações interdimensionais para Cordia trichotoma (Vell.) Arráb. Ex Steud. Ciência Florestal, 19(4), 473-480. https://doi.org/10.5902/ 19805098901

Rudnicki, M., Silins, U., Liefferd, V. J., \& Josi, G. (2001). Measure of simultaneous tree sways and estimation of crown interactions among a group of trees. Trees, 15, 83-90. https://doi.org/10.1007/s004680000080

Ruel, J. C. (2000). Factors influencing wind throw in Balsam Fir Forest. Forest Ecology and Management, 135(1-3), 169-178. https://doi.org/10.1016/S0378-1127(00)00308-X

Sanquetta, C. R., Corte, A. P. D., Roglin, A., \& Pimentel, A. (2013). Relações diâmetro-altura para espécies lenhosas em um fragmento de floresta Ombrófila Mista no Sul do Paraná. Iheringia, Série Botânica, 68(1), 103-114.

SAS. (2004). The SAS System for Windows. Cary: SAS Institute.

Šebeň, V., Bošel'a, M., Konopka, B., \& Pajtik, J. (2013). Indices of tree competition in dense spruces stand originated from natural regeneration. Lesnícky časopis - Forestry Journal, 59(3), 172-179.

Selle, G. L., \& Vuaden, E. (2010). Crescimento de seis espécies nativas da região central do estado do Rio Grande do Sul. Ambiência, 6(1), 169-192.

Silveira, A. C. da, Hess, A. F., Schorr, L. P. B., Krefta, S. M., Santos, D. V. dos, Filho, M. D. H. V., ... Borsoi, G. A. (2018). Management of Brazilian pine (Araucaria angustifolia (Bertol) Kuntze) based on the Liocourt model in a mixed ombrophilous forest in Southern Brazil. Australian Journal of Crop Science, 12(02), 311-317. https://doi.org/10.21475/ajcs.18.12.02.pne927 
Tonini, H., \& Arco-Verde, M. F. (2005). Morfologia da copa para avaliar o espaço vital de quatro espécies nativas da Amazônia. Pesquisa Agropecuária Brasileira, 40(7), 633-638. https://doi.org/10.1590/S0100-204 X2005000700002

Vanclay, J. K. (2009). Tree diameter, height and stocking in even-aged forests. Annals of Forest Science, 66(702), 1-7. https://doi.org/10.1051/forest/2009063

Wadsworth, F. H. (2000). Producción forestal para América Tropical (p. 602). Washington: USDA.

Weber, V. P., Finger, C. A. G., Fleig, F. D., Souza, C. A. M., Munareto, F. F., \& Silva, L. T. M. (2013). Diretrizes para desbaste de Pinus taeda L. em função da altura dominante. Ciência Florestal, 23(1), 193-201. https://doi.org/10.5902/198050988453

\section{Copyrights}

Copyright for this article is retained by the author(s), with first publication rights granted to the journal.

This is an open-access article distributed under the terms and conditions of the Creative Commons Attribution license (http://creativecommons.org/licenses/by/4.0/). 